\title{
Pelaksanaan Misi Allah dalam Konteks Keragaman Budaya di Indonesia
}

\author{
Sigit Wijoyo \\ Sekolah Tinggi Teologi Bethel Ambon \\ Korepondensi: sigitwijoyo1978@gmail.com
}

\begin{abstract}
Abstrak: Pelaksanaan misi Allah dalam konteks keragaman budaya di Indonesia penting dipelajari mengingat gereja memiliki tanggungjawab menjalankan Amanat Agung Tuhan Yesus kepada bangsa-bangsa. Keadaan masyarakat Indonesia yang beragam budaya, merupakan tantangan yang berat bagi para pemberita injil karena mereka tidak dapat menerapkan satu metode khusus yang dapat dipakai kepada seluruh masyarakat. Beberapa gereja masih menerapkan model misi yang diwariskan oleh Zending. Model Kolonial tersebut dinilai kurang efektif dengan adanya budaya masyarakat Indonesia yang telah berkembang. Oleh karena itu diperlukan prinsip-prinsip pelaksanaan misi yang luwes, sesuai dengan konteks masyarakat di Indonesia tanpa mengurangi makna injil yang alkitabiah. Artikel ini disusun dengan meneliti fakta kehidupan budaya masyarakat Indonesia yang beragam budaya dan meneliti firman Allah yang memuat ajaran tentang prinsip pemberitaan injil bagi segala bangsa. Proses penelitian dalam artikel ini dilakuakan dengan melakukan penelitian kepustakaan tentang kondisi keragaman budaya di Indonesia serta meneliti catatan alkitab yang relevan dalam pelaksanaan misi di Indonessia. Hasilnya adalah model pelaksanaan misi dengan memperhatikan konteks budaya, misi yang kristosentris tanpa menghilangkan nilainilai keIndonesiaan masyarakat lokal.
\end{abstract}

Kata kunci: misi Allah, amanat agung, keragaman budaya

\begin{abstract}
The implementation of God's mission in the context of cultural diversity in Indonesia is important to study considering that the church has the responsibility to carry out the Great Commission of the Lord Jesus to the nations. The culturally diverse situation of Indonesian society poses a formidable challenge for evangelists because they cannot apply one specific method that can be applied to the entire community. Some churches still apply the mission model inherited by Zending. The Colonial Model is considered less effective due to the growing culture of Indonesian society. Therefore, flexible mission implementation principles are needed, according to the context of society in Indonesia without compromising the biblical meaning of the gospel. This article was compiled by examining the facts of the cultural life of the Indonesian people who are diverse in culture and examining the word of God which contains teachings on the principle of preaching the gospel to all nations. The research process in this article is carried out by conducting library research on the condition of cultural diversity in Indonesia and examining relevant biblical records in carrying out missions in Indonesia. The result is a mission implementation model that takes into account the cultural context, a christocentric mission without losing the Indonesian values of the local community.
\end{abstract}

Keywords: God's mission, great commission, cultural diversity 


\section{PENDAHULUAN}

Tugas penyelenggaraan misi Allah menjadi sentral dalam Alkitab baik dalam Perjanjian Lama maupun Perjanjian Baru. Hadirnya Alkitab dan kekristenan pada masa kini merupakan buah misi Allah bagi dunia. Misi Allah yang sedianya dilaksanakannya melalui bapa-bapa beriman, kemudian dilanjutkan oleh suatu bangsa pilihan, yaitu Israel dan kemudian gereja menggantikan Israel dalam melanjutkan misi Allah bagi bangsa-bangsa. Fakta tersebut menegaskan bahwa keseluruhan rencana kerja Allah berorientasi pada misi penyelamatan jiwajiwa.

Salah satu mandat gereja adalah bersaksi tentang keselamatan yang disediakan Allah di dalam Yesus Kristus. Dalam menjalankan mandat kesaksian, gereja telah diperlengkapi dengan kuasa dari Roh Kudus sehingga pekerjaan misi yang mereka lakukan dalam pengawasan Roh Kudus. Namun, gereja atau lembaga misi juga harus memperhatikan konteks masyarakat dimana mereka menjalankan misi Allah.

Penelitian ini akan membahas tentang pekerjaan misi dalam konteks masyarakat maupun bangsa. Beberapa penelitian menekankan pada metode pemberitaan injil secara umum. ${ }^{1}$ Sedangkan ada penelitian yang menekankan pada prinsip-prinsip alkitabiah pelaksanaan misi Allah. ${ }^{2}$ Berbeda dengan beberapa tulisan tentang misi, yang bersifat universal, tulisan ini akan menyoroti prinsipprinsip misi dalam konteks keragaman budaya di Indonesia. Dewasa ini para teolog, misiolog maupun pelayan gerejawi perlu memperhatikan fenomena munculnya berbagai macam metode pelaksanaan misi di Indonesia yang kurang dapat menjangkau budaya Indonesia atau mereduksi ke-Indonesiaan penduduk setempat. Tentu saja, hal ini dapat menuai reaksi negatif berupa

${ }^{1}$ Phill Butler, "Who's In and Who's Out? Reflections on Our Biblical Understanding of the Gospel," International Buletin of Mission Research 00 (2019): $1-9$.

${ }^{2}$ Esau Huwae, "Prinsip Dasar Pemberitaan Injil Menurut Kisah Para Rasul 28:23-31,” Kapata 1 (2020): 119-136. penolakan dari kaum radikal atau masyarakat biasa.

Indonesia merupakan negara dengan beranekaragam budaya (multikultur). Charles A. Coppel memberikan respon negatif terhadap fakta tolelaransi penerimaan keanekaragaman budaya. Dalam tulisannya, dia mengatakan bahwa status Indonesia sebagai negara multikultur merupakan klise yang selama ini didengung-dengungkan. ${ }^{3}$ Penilaian ini tidak dapat diabaikan oleh para misionaris atau pekerja misi di Indonesia. Sindiran dari Coppel harus ditanggapi dengan hadirnya suatu program misi yang sesuai dengan keanekaragaman budaya di Indonesia. Artinya, misi di Indonesia tidak perlu menghilangkan identitas ke-Indonesiaan, melainkan memberikan warna baru terhadap budaya Indonesia.

Acuan utama bagi terwujudnya masyarakat Indonesia yang memiliki keanekaragaman budaya adalah multikulturalisme, yaitu sebuah ideologi yang mengakui dan mengagungkan perbedaan dalam kesetaraan, baik secara individual maupun kebudayaan. ${ }^{4}$ Agama dan berbagai macam ritual merupakan bagian dari budaya. Artinya, kekristenan dan misi merupakan bagian dari budaya Indonesia. Dengan demikian hadirnya kekristenan di Indonesia merupakan wujud penerimaan masyarakat lokal (Indonesia) terhadap ajaran, ritual serta amanah yang terkandung dalam agama Kristen. Gereja dan pra misionaris perlu memanfaatkan fakta tersebut dalam rangka menyebarkan kebenaran injil kepada masyarakat lokal lainnya.

Hadirnya gereja-gereja suku telah mengakomodasi penerimaan kekristenan oleh budaya lokal. Meskipun hadirnya gereja suku bukan tujuan utama pemberitaan misi, namun melalui berdirinya gereja-gereja suku menunjukkan bahwa ajaran kekristenan dapat diterima dan terhisap dalam budaya masyarakat lokal. Hal ini tentunya membuka peluang

${ }^{3}$ Charles A. Coppel, "Historical Impediments to the of Ethnic Chinese in a Multicultural Indonesia," Antropologi Indonesia 71 (2003): 13-22.

${ }^{4}$ Parsudi Suparlan, "Menuju Masyarakat Indonesia Yang Multikultural," Antropologi Indonesia 69 (2002): 98105. 
terbentuknya gereja-gereja di Indonesia yang mampu mengakomodasi budaya lokal. Dengan demikian gereja dapat menjalankan mandat ilahi, yaitu Amanat Agung dan mandat budaya secara bersama-sama.

Apakah kekristenan perlu diejawantahkan menjadi suatu tradisi dalam suatu komunitas masyarakat? Paulus, dalam surat 1 Koritus menggunakan tradisi kekristenan dalam upaya membangun kerohanian orang-orang Kristen di Korintus. Kenneth E. Bailey mencatatkan setidaknya ada beberapa tradisi kekristenan yang dipakai Paulus dalam memperbaiki moralitas dan kerohanian orang Kristen di Korintus, antara lain; Pertama, tradisi yang berisi kesaksian tentang Kristen yang diterima oleh orang-orang di Korintus (1 Kor. 6). Kedua, tradisi yang dilakukan oleh Yesus yang diajarkan oleh Paulus di berbagai jemaat (1 Kor. 4:17). Ketiga, tradisi yang diungkapkan melalui pengakuan atau kredo (1 Kor. 8:6). Keempat, tradisi gereja mula-mula yang harus dipelihara yang disampaikan kepada jemaat di Korintus (1 Kor. 11:23-26). Kelima, tradisi pengakuan jemaat mula-mula yang diteruskan kepada jemaat di Koritus (1 Kor. $15: 3-5)^{5}$

Berdasarkan penelitian Kenneth E. Bailey di atas, maka dapat dipahami bahwa ajaran Kristen yang diwariskan secara turun temurun dapat menjadi tradisi yang menjadi identitas Kekristenan itu sendiri. Keberagaman budaya di Indonesia membuka peluang munculnya budayabudaya baru yang tentunya sesuai dengan filosofi orang Timur, yaitu budaya yang menjunjung tinggi nilai-nilai moral dan spiritual. Peluang ini yang seharusnya dimanfaatkan oleh orang percaya di Indonesia dengan cara mewarnai budaya Indonesia dengan budaya Kristen yang selaras dengan budaya Indonesia.

Kegagalan misi pemberitaan injil biasanya dimulai dari kegagalan memahami konteks budaya setempat. Seorang pekerja misi di Indonesia yang cenderung membawa budaya kekristenan barat akan cenderung kesulitan masuk kedalam budaya masyarakat lokal. Selain

${ }^{5}$ Keneth E Bailey, Paul Through Mediteranian Eyes: Cultural Studies In 1 Corinthians (Downers Grove: IVP Academic, 2011), 424-425 itu, stigma liberalis yang disematkan pada orang barat dan budayanya cenderung menjadi penghambat pelaksanaan misi. Tentu saja fakta bahwa sejauh ini pemberitaan injil bergantung pada badan misi atau organisasi misi dari luar negeri justru dapat dianggap sebagai penjajahan budaya oleh beberapa oknum tertentu.

Ada beberapa golongan yang mencobaa mengaburkan makna misi dengan kegiatankegiatan sosial. Mereka mendasari argumentasi mereka dengan perkataan Tuhan Yesus dalam injil Matius 22:37-40. Kalimat, "kasihilah sesamamu seperti dirimu sendiri” diyakini sebagai mandat utama kekristenan. Golongan ini kurang melihat definisi injil secara komprehensif karena hanya memperhatikan hubungan horizontal, yaitu antara manusia dengan manusia, tanpa memperhatikan hubungan vertikal, yaitu menghubungkan manusia dengan Allah yang menyelamatkan. Dampak dari model pekerjaan misi ini adalah kekristenan dianggap tidak lebih dari organisasi sosial. Sesungguhnya, hadirnya kekristenan tidak hanya memperbaiki masalah sosial, tetapi juga masalah spiritual manusia yang merupakan masalah paling esensial.

Apa yang harus dilakukan oleh gereja, pekerja misi atau orang percaya dalam menjalankan misi dalam konteks keberagaman budaya di Indonesia? Penelitian ini akan membahas tentang kontribusi gereja dalam rangka menjalankan misi Allah bagi pemenuhan amanat agung Tuhan Yesus Kristus. Peneliti akan mengupas landasan biblika pelaksanaan misi Allah dalam konteks keberagaman budaya di Indonesia. Selanjutnya, peneliti akan mengidentifikasi kondisi dan realitas keberagaman budaya di Indonesia. Pada akhirnya, penelitian ini akan menghasilkan rumusan model pelayanan misi dalam konteks keberagaman budaya di Indonesia.

\section{METODE}

Jenis penelitian yang dilakukan adalah penelitian kualitatif dengan tipe penelitian historis. Menurut Muri Yusuf menjelaskan ada beberapa ciri khusus penelitian historis adalah sebagai berikut; Pertama, penelitian historis 
lebih banyak bergantung pada data yang ditulis atau dicatat pada masa lampau. Kedua, penelitian historis bergantung pada data primer. Dalam konteks penelitian teologi, data primer atau sumber utama adalah Alkitab. Ketiga, penelitian historis mirip dengan penelitian kepustakaan. ${ }^{6}$

Model penelitian yang dilakukan adalah penelitian teologi yang akan lebih banyak menekankan pada penyelidikan kepustakaan yaitu Alkitab sebagai sumber primer atau sumber utama dan buku-buku tafsiran dan pustaka terkait informasi keberagaman suku di Indonesia sebagai sumber sekunder atau sumber pendukung. Langkah-langkah praktis yang akan dilakukan adalah sebagai berikut:

Pertama, mengumpulkan informasi terkait kondisi keberagaman budaya di Indonesia. Pada bagian ini peneliti akan memanfaatkan beberapa buku dan jurnal yang relevan dengan penelitian peneliti. Tujuan dari tahap ini adalah untuk mengumpulkan berbagai macam informasi yang memuat fakta dan pelaksanaan kehidupan masyarakat Indonesia dalam keberagaman budaya. Berdasarkan informasi yang telah diperoleh, maka peneliti dapat menentukan ajaran alkitab yang relevan dengan situasi dan kondisi masyarakat di Indonesia.

Kedua, memaparkan ajaran Alkitab tentang mandat misi kepada segala bangsa. Setelah memahami konteks kehidupan masyarakat di Indonesia yang memiliki keanekaragaman budaya, maka pada bagian ini peneliti akan menetapkan teks alkitab yang memuat mandat pemberitaan injil kepada bangsa-bangsa yang multietnis dan multikultur. Tujuan pemaparan kebenaran firman Allah adalah untuk memperkuat landasan teologis yang menjadi pedoman pelaksanaan misi di Indonesia. Dengan demikian, pendeta, pekerja misi dan orang percaya dapat menjalankan misi secara seimbang. Artinya, selain menekankan pada praktek atau program pelaksanaan misi, orang percaya melaksanakan misinya berdasarkan teologi alkitabiah.

${ }^{6}$ Muri Yusuf, Penelitian Kuantitatif, Kualitatif Dan Gabungan (Jakarta: Kencana, 2017), 144.
Ketiga, memaparkan rumusan model pelayanan misi dalam konteks keberagaman budaya di Indonesia. Tahap ini adalah puncak penelitian yang dilakukan oleh peneliti. Setelah peneliti memperoleh gambaran keragaman budaya di Indonesia dan landasan biblika terhadap pelaksanaan misi di Indonesia, maka peneliti akan merumuskan dasar dan model pelayanan misi di Indonesia. Dasar dan model pelayanan misi di Indonesia akan menjadi masukan penting bagi pendeta, pekerja misi dan orang percaya dalam menjalan misi sesuai dengan kebenaran Alkitab dan dapat menjangkau berbagai macam budaya yang ada di Indonesia.

\section{PEMBAHASAN}

Persoalan kebangsaan bagi sebuah bangsa yang sangat plural seperti Indonesia merupakan hal yang sangat krusial. Ancaman disintegrasi bangsa selalu membayangi. Berbagai hal mengancam kesatuan Indonesia sebagai sebuah bangsa, di antaranya berkaitan dengan kedaerahan, berkaitan dengan bangsa lainnya, dengan perebutan kekuasaan, serta hal-hal yang berkaitan dengan ideologi, konsep, dan pandangan hidup yang mungkin dianggap berbeda. $^{\text {? }}$

Selain keragaman budaya di Indonesia merupakan sebuah anugerah Tuhan bagi bangsa ini, tetapi kondisi perbedaan budaya juga berpotensi sebagai tembok pemisah antara satu kelompok dengan kelompok lainnya. Perbedaanperbedaan di antara masing-masing kelompok masyarakat memberikan peluang yang cukup besar terhadap terjadinya pertentangan maupun pertikaian di antara masing-masing kelompok. Lambang Triyono mengatakan bahwa dari sudut pendekatan multi-dimensi, kita menemukan konflik di Indonesia sekarang berada dalam tiga konteks nasional; politik, sosial dan kultural. ${ }^{8}$

${ }^{7}$ Sunu Wasono, "Narasi Kebangsaan Dalam Karya Budaya Indonesia," in Narasi Kebangsaan Dalam Karya Budaya Indonesia, ed. Wasono Sunu (Jakarta: LIPI Press, 2020), 1.

${ }^{8}$ Lambang Trijono, Potret Retak Nusantara: Studi Kasus Konflik Di Indonesia (Yogyakarta: CSPS Books, 2004), 3. 
Jika hal demikian dibiarkan terjadi, maka kelompok yang kuat akan lebih dominan dan berkuasa, sedangkan kelompok yang lemah dianggap minoritas. Oleh karena itu, semboyan Bhineka Tunggal Ika merupakan ruh penggerak kesatuan antar masyarakat di Indonesia.

Mengutip dari Portal Informasi Indonesia, berdasarkan sensus Badan Pusat Statistik tahun 2010, Indonesia memiliki lebih dari 300 kelompok etnik atau suku bangsa, lebih tepatnya 1.340 suku bangsa. ${ }^{9}$ Demikian banyaknya suku bangsa yang ada di Indonesia, berdampak pada beragam pula budaya yang dimiliki oleh masingmasing suku bangsa. Fakta ini menegaskan bahwa keragaman budaya di Indonesia telah terjalin dengan baik yang dibuktikan mereka dapat hidup bersama-sama sebagai bangsa yang merdeka, yaitu bangsa Indonesia.

Konstitusi negara juga mengakui keragaman budaya di Indonesia, salah satunya berkaitan dengan kepercayaan yang dianut. Landasan ideologi negara Indonesia, yaitu Pancasila pada ayat pertama menyatakan, "Ketuhanan yang Maha Esa" dan diejawantahkan dalam UndangUndang Pasal 29 ayat 1 dan 2 yang intinya adalah menghormati kebebasan seluruh rakyat Indonesia memeluk agamanya masing-masing. Dalam konteks multikultural, regulasi mengenai keyakinan terhadap agama tertentu memang perlu diatur, mengingat bahwa keyakinan atas ajaran agama berpotensi menimbulkan konflik di antara oknum-oknum yang kurang bertanggungjawab. Biasanya diawali dengan radikalisme yang disalurkan dengan kegiatan yang negatif. ${ }^{10}$ Dengan regulasi yang telah ditetapkan oleh pemerintah, maka rakyat Indonesia memiliki jaminan dalam beribadah dan mengamalkan ajaran agama yang diyakininya.

Jadi, dalam konteks mandat budaya, gereja perlu memperhatikan bahwa mereka bagian dari bangsa Indonesia yang diakui dan dilindungi oleh regulasi pemerintah Republik Indonesia. Selain menjadi hak istimewa, pengakuan dan perlindungan tersebut memberikan amanat bahwa gereja juga harus memiliki kontribusi dalam pembangunan masyarakat Indonesia yang dami sejahtera, adil dan makmur. Salah satu cara yang dapat dilakukan gereja dalam memberikan kontribusi bagi bangsa adalah dengan membangun kerohanian masyarakat Indonesia untuk mewujudkan masyarakat yang damai.

Masyarakat Indonesia merupakan masyarakat yang menjunjung tinggi nilai-nilai keagamaan. Selain agama yang diakui oleh negara, ada berbagai macam aliran kepercayaan yang dianut oleh masing-masing suku bangsa. Meskipun letak geografis Indonesia merupakan negara kepulauan, namun fakta yang harus disadari adalah seluruh masyarakat di Indonesia menjunjung tinggi kepercayaan (agama) yang mereka yakini. Artinya, meskipun mereka terpisah secara geografis, namun spirit terhadap keagamaan tetap sama, meskipun dalam berbagai konsep yang berbeda. Selain menjadi tantangan dalam pemberitaan injil, kondisi tersebut membuka peluang memberitakan injil yang membaharui spiritualitas mereka.

Hubungan antara misi Tuhan Yesus dan orang percaya termaktub dalam bagian pertama Kisah Para Rasul. Frase, "tentang segala sesuatu yang dikerjakan dan diajarkan Yesus" menjelaskan bahwa orang percaya mewarisi misi Tuhan Yesus. ${ }^{11}$ Kisah Para Rasul 1:8 berkata, "Tetapi kamu akan menerima kuasa, kalau Roh Kudus turun ke atas kamu, dan kamu akan menjadi saksi-Ku di Yerusalem dan di seluruh Yudea dan Samaria dan sampai ke ujung bumi." ${ }^{2}$ Peneliti mencoba menafsirkan bagian tersebut dengan lensa misiologi dan entografi dengan bagan sebagai berikut:

${ }^{9}$ Diambil dari laman resmi pemerintah Republik Indonesia https://indonesia.go.id/profil/suku-bangsa (diakses pada tanggal 10 Januari 2021).

${ }^{10}$ Agustinus Wisnu Dewantara, "Radikalisme Agama dalam Konteks Indonesia yang Agamis dan Berpancasila," JPAK: Jurnal Pendidikan Agama Katolik 19, no. 1 (April 17, 2019): 1-14, https://ejournal. widyayuwana.ac.id/index.php/jpak/article/view/222.

${ }^{11}$ Michael W. Goheen, A Light to the Nations: The Missional Church and the Biblical Story (Grand Rapids: Baker Academic, 2011), 122.

12“Kitab Kisah Para Rasul," in Alkitab Terjemahan Baru (Jakarta: Lembaga Alkitab Indonesia, 2012). 


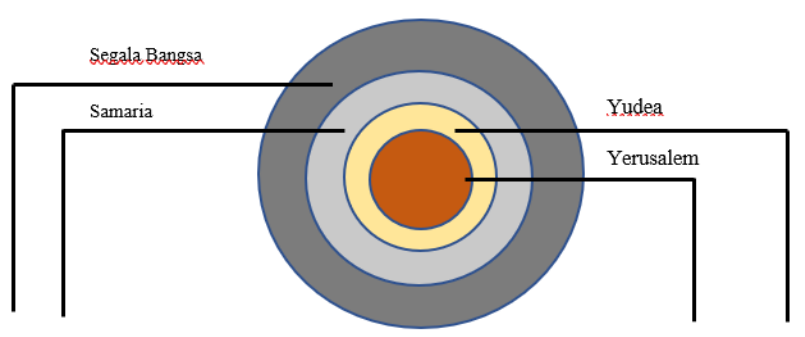

Bagan tersebut menggambarkan pembagian target pemberitaan injil berdasarkan topografis. Yerusalem menjelaskan kota tempat tinggal, artinya orang-orang terdekat dengan budaya dan kebiasaan yang sama. Yudea menjelaskan orangorang yang memiliki budaya yang sama. Samaria menjelaskan tentang jangkauan pada orang yang agak jauh dari budaya kita, tetapi seragam. Contohnya, Indonesia dengan budaya Melayu. Meskipun Indonesia memiliki budaya yang berbeda dengan Malaysia dan Brunei Darussalam, tetapi merupakan serumpun. Ujung bumi atau segala bangsa menjelaskan pada budaya yang berbeda.

Kisah Para Rasul 1:8 merupakan perkembangan dari nubuatan kitab Yesaya 49:6, bahwa Tuhan menghendaki umatnya menjadi terang bagi bangsa-bangsa. Dengan menyampaikan perintah yang mengandung penegasan nubuatan, maka para murid akan menggambil bagian dari rencana Allah, yaitu dengan menjadi saksi kepada bangsa-bangsa. Para murid akan memulai dari Yerusalem sampai akhirnya segala bangsa akan dijangkau oleh injil. $^{13}$

Berikut ini adalah analisis pendekatan misi Yesus Kristus, para murid dan orang percaya menurut Injil Lukas dan Kisah Para Rasul.

\section{Analisis Pendekatan Yesus Kristus menurut Injil Lukas}

Bagian ini peneliti memaparkan hasil observasi dan penelaahan terhadap pola pelayanan Yesus dalam upaya memberitakan injil berdasarkan catatan injil Lukas. Peneliti menilai bahwa Lukas memberikan catatan yang lebih

${ }^{13}$ Charles H. Talbert, Reading Act: (Macon: Smyth \& Helwys Publishing, 2005), 9. lengkap tentang pekerjaan misi Yesus dibandingkan keempat injil lainnya.

\begin{tabular}{|c|c|c|c|}
\hline Nats & Aktivitas & Tempat & $\begin{array}{c}\text { Tanggapan } \\
\text { Orang }\end{array}$ \\
\hline $\begin{array}{c}\text { Luk. } \\
4: 14-15\end{array}$ & $\begin{array}{l}\text { Yesus } \\
\text { Kristus } \\
\text { mengajar }\end{array}$ & $\begin{array}{l}\text { Ditempat- } \\
\text { tempat } \\
\text { ibadah di } \\
\text { Galilea. }\end{array}$ & $\begin{array}{l}\text { Semua orang } \\
\text { di Galilea } \\
\text { memuji Dia }\end{array}$ \\
\hline $\begin{array}{c}\text { Luk. } \\
\text { 4: } 16-19\end{array}$ & $\begin{array}{l}\text { Yesus } \\
\text { Kristus } \\
\text { berdiri dan } \\
\text { membaca } \\
\text { kitab Yesaya }\end{array}$ & $\begin{array}{l}\text { Rumah } \\
\text { ibadat di } \\
\text { Nazaret. }\end{array}$ & $\begin{array}{l}\text { Belum ada } \\
\text { respon dari } \\
\text { orang-orang } \\
\text { sekitar. }\end{array}$ \\
\hline $\begin{array}{c}\text { Luk. } \\
4: 20-22\end{array}$ & \begin{tabular}{l|} 
Yesus \\
Kristus \\
menjelas- \\
kan \\
pengajaran \\
dari kitab \\
Yesaya yang \\
telah \\
dibacanya. \\
\end{tabular} & $\begin{array}{l}\text { Rumah } \\
\text { ibadat di } \\
\text { Nazaret. }\end{array}$ & $\begin{array}{l}\text { Orang-orang } \\
\text { terkagum dan } \\
\text { membenar- } \\
\text { kannya (22). }\end{array}$ \\
\hline $\begin{array}{c}\text { Luk. } \\
4: 22-30\end{array}$ & \begin{tabular}{l|} 
Yesus \\
Kristus \\
menolak \\
melakukan \\
mujizat \\
seperti yang \\
dijelaskan \\
di \\
Kapernaum
\end{tabular} & Nazaret & $\begin{array}{l}\text { Orang-orang } \\
\text { menolak } \\
\text { Yesus Kristus } \\
\text { dan hendak } \\
\text { melemparkan } \\
\text { ke jurang. }\end{array}$ \\
\hline $\begin{array}{c}\text { Luk. } \\
4: 31-34\end{array}$ & $\begin{array}{l}\text { Yesus } \\
\text { Kristus } \\
\text { mengajar } \\
\text { pada hari } \\
\text { sabat }\end{array}$ & $\begin{array}{l}\text { Rumah } \\
\text { ibadat di } \\
\text { Kapernaum }\end{array}$ & $\begin{array}{l}\text { Orang-orang } \\
\text { takjub dengan } \\
\text { perkataanNya } \\
\text { yang penuh } \\
\text { kuasa }\end{array}$ \\
\hline $\begin{array}{c}\text { Luk. } \\
4: 34-37\end{array}$ & $\begin{array}{l}\text { Yesus } \\
\text { Kristus } \\
\text { mengusir } \\
\text { setan }\end{array}$ & $\begin{array}{l}\text { Rumah } \\
\text { ibadat di } \\
\text { Kapernaum }\end{array}$ & $\begin{array}{l}\text { 1. Setan } \\
\text { keluar. } \\
\text { 2. Orang } \\
\text { takjub } \\
\text { 3. Orang } \\
\text { memberita- } \\
\text { kan } \\
\text { peristiwa } \\
\text { tersebut }\end{array}$ \\
\hline $\begin{array}{c}\text { Luk. } \\
4: 38-40\end{array}$ & $\begin{array}{l}\text { Yesus } \\
\text { Kristus } \\
\text { menyembu } \\
\text { hkan } \\
\text { (mertua } \\
\text { Simon) }\end{array}$ & $\begin{array}{l}\text { Rumah } \\
\text { Simon }\end{array}$ & $\begin{array}{l}\text { Orang-orang } \\
\text { senang, namun } \\
\text { merahasiakan } \\
\text { keMesiasannya } \\
\text { atas permin- } \\
\text { taan Yesus } \\
\text { Kristus sendiri. }\end{array}$ \\
\hline
\end{tabular}


HUPĒRETĒS: Jurnal Teologi dan Pendidikan Kristen 2 no. 2 (2021)

\begin{tabular}{|c|c|c|c|c|c|c|c|}
\hline \multirow{2}{*}{$\begin{array}{c}\text { Luk. } \\
4: 42-43\end{array}$} & \multirow{2}{*}{\begin{tabular}{l|} 
Yesus \\
Kristus \\
memberita- \\
kan injil
\end{tabular}} & \multirow[b]{2}{*}{$\begin{array}{l}\text { Tempat } \\
\text { yang sunyi } \\
\text { dan dalam } \\
\text { rumah } \\
\text { ibadat di } \\
\text { Yudea }\end{array}$} & \multirow{2}{*}{$\begin{array}{l}\text { Orang-orang } \\
\text { menahan } \\
\text { Yesus Kristus. }\end{array}$} & & & & Yesus Kristus. \\
\hline & & & & $\begin{array}{c}\text { Luk. } \\
\text { 6:12-16 }\end{array}$ & \begin{tabular}{l|} 
Yesus \\
Kristus \\
berdoa dan \\
memilih \\
para rasus
\end{tabular} & Di Bukit & $\begin{array}{l}\text { Dua belas } \\
\text { rasul } \\
\text { mengikuti } \\
\text { Yesus Kristus. }\end{array}$ \\
\hline \multirow[t]{2}{*}{$\begin{array}{l}\text { Luk. } \\
\text { 5:1-11 }\end{array}$} & \multirow[t]{2}{*}{$\begin{array}{l}\text { Yesus } \\
\text { Kristus } \\
\text { mengajar, } \\
\text { memberita- } \\
\text { kan injil, } \\
\text { dan } \\
\text { melakukan } \\
\text { mujizat } \\
\end{array}$} & \multirow[t]{2}{*}{$\begin{array}{l}\text { Danau } \\
\text { Genesaret }\end{array}$} & \multirow[t]{2}{*}{$\begin{array}{l}\text { Yakobus, } \\
\text { Yohanes dan } \\
\text { Simon } \\
\text { menjadi } \\
\text { pengikutNya. }\end{array}$} & $\begin{array}{c}\text { Luk. } \\
\text { 6:17-49 }\end{array}$ & $\begin{array}{l}\text { Yesus } \\
\text { Kristus } \\
\text { mengajar } \\
\text { dan } \\
\text { menyem- } \\
\text { buhkan } \\
\text { orang }\end{array}$ & $\begin{array}{l}\text { Di bawah } \\
\text { bukit }\end{array}$ & $\begin{array}{l}\text { Orang banyak } \\
\text { mendengar- } \\
\text { kan Dia dan } \\
\text { berharap } \\
\text { disembuhkan } \\
\text { oleh Dia. }\end{array}$ \\
\hline & & & & \multirow{2}{*}{$\begin{array}{l}\text { Luk. } \\
\text { 7:1-17 }\end{array}$} & \multirow[b]{2}{*}{$\begin{array}{l}\text { Yesus } \\
\text { Kristus } \\
\text { menyem- } \\
\text { buhkan } \\
\text { hamba } \\
\text { perwira dan } \\
\text { membang- } \\
\text { kitkan } \\
\text { orang mati }\end{array}$} & \multirow[b]{2}{*}{$\begin{array}{l}\text { Kapernaum } \\
\text { dan Nain }\end{array}$} & \multirow[b]{2}{*}{$\begin{array}{l}\text { Semua orang } \\
\text { takut dan } \\
\text { memuliakan } \\
\text { Allah serta } \\
\text { menganggap } \\
\text { bahwa Ia } \\
\text { adalah nabi } \\
\text { yang besar. }\end{array}$} \\
\hline $\begin{array}{c}\text { Luk. } \\
\text { 5:12-16 }\end{array}$ & $\begin{array}{l}\text { Yesus } \\
\text { Kristus } \\
\text { menyem- } \\
\text { buhkan } \\
\text { (orang sakit } \\
\text { kusta) }\end{array}$ & $\begin{array}{l}\text { Berada } \\
\text { dalam } \\
\text { sebuah kota }\end{array}$ & $\begin{array}{l}\text { Kabar tentang } \\
\text { Yesus Kristus } \\
\text { mekin } \\
\text { tersebar luas } \\
\text { dan banyak } \\
\text { orang } \\
\text { mencari } \\
\text { Yesus Kristus. }\end{array}$ & & & & \\
\hline \multirow[t]{2}{*}{$\begin{array}{c}\text { Luk. } \\
\text { 5:17-26 }\end{array}$} & \multirow[t]{2}{*}{$\begin{array}{l}\text { Yesus } \\
\text { Kristus } \\
\text { mengajar } \\
\text { dan } \\
\text { menyem- } \\
\text { buhkan } \\
\text { orang } \\
\text { lumpuh }\end{array}$} & \multirow[t]{2}{*}{$\begin{array}{l}\text { Tidak } \\
\text { dijelaskan } \\
\text { secara pasti } \\
\text { tempatnya. } \\
\text { Namun } \\
\text { kemungki- } \\
\text { nan berada } \\
\text { di sinagoge, } \\
\text { sebab itulah } \\
\text { tempat yang } \\
\text { dipakai } \\
\text { untuk } \\
\text { mengajar } \\
\text { bagi orang- } \\
\text { orang } \\
\text { Yahudi. }\end{array}$} & \multirow[t]{2}{*}{$\begin{array}{l}\text { 1. Orang } \\
\text { Farisi dan } \\
\text { Ahli Taurat } \\
\text { menolak. } \\
\text { 2. Orang } \\
\text { banyak } \\
\text { takjub dan } \\
\text { memulia- } \\
\text { kan Allah. }\end{array}$} & $\begin{array}{l}\text { Luk. } \\
\text { 9:1-6 }\end{array}$ & $\begin{array}{l}\text { Yesus } \\
\text { Kristus } \\
\text { memberi- } \\
\text { kan kuasa } \\
\text { dan } \\
\text { mengutus } \\
\text { para murid } \\
\text { untuk } \\
\text { memberita- } \\
\text { kan injil } \\
\text { dan } \\
\text { melakukan } \\
\text { mujizat }\end{array}$ & $\begin{array}{l}\text { Di Kota } \\
\text { (mungkin } \\
\text { masih } \\
\text { disekitar } \\
\text { Kapernaum) }\end{array}$ & $\begin{array}{l}\text { Murid-murid } \\
\text { memberita- } \\
\text { kan injil dan } \\
\text { menyembuh- } \\
\text { kan orang } \\
\text { sakit di desa- } \\
\text { desa. }\end{array}$ \\
\hline & & & & \multirow[t]{2}{*}{$\begin{array}{c}\text { Luk. } \\
\text { 9:10-17 }\end{array}$} & \multirow{2}{*}{$\begin{array}{l}\text { Yesus } \\
\text { Kristus } \\
\text { melakukan } \\
\text { mujizat } \\
\text { dengan cara } \\
\text { memberi } \\
\text { makan lima } \\
\text { ribu orang }\end{array}$} & \multirow[t]{2}{*}{ Betsaida } & \multirow{2}{*}{$\begin{array}{l}\text { Semuanya } \\
\text { makan } \\
\text { sampai } \\
\text { kenyang. }\end{array}$} \\
\hline \multirow[t]{2}{*}{$\begin{array}{c}\text { Luk. } \\
\text { 5:27-32 }\end{array}$} & \multirow{2}{*}{$\begin{array}{l}\text { Yesus } \\
\text { Kristus } \\
\text { mengajak } \\
\text { seseorang } \\
\text { (Lewi) } \\
\text { untuk } \\
\text { mengikuti } \\
\text { Dia }\end{array}$} & \multirow[t]{2}{*}{$\begin{array}{l}\text { Tempat } \\
\text { pemungu- } \\
\text { tan cukai } \\
\text { dan rumah } \\
\text { Lewi }\end{array}$} & \multirow{2}{*}{$\begin{array}{l}\text { 1. Lewi } \\
\text { mengikuti } \\
\text { Dia } \\
\text { 2. Orang } \\
\text { Farisi dan } \\
\text { Ahli Taurat } \\
\text { bersungut- } \\
\text { sungut. }\end{array}$} & & & & \\
\hline & & & & \multirow[t]{2}{*}{$\begin{array}{c}\text { Luk. } \\
9: 51-56\end{array}$} & \multirow{2}{*}{$\begin{array}{l}\text { Yesus } \\
\text { Kristus } \\
\text { berjalan ke } \\
\text { Yerusalem } \\
\text { melalui } \\
\text { Samaria }\end{array}$} & \multirow[t]{2}{*}{ Samaria } & $\begin{array}{l}\text { Orang } \\
\text { Samaria } \\
\text { menolak }\end{array}$ \\
\hline \multirow[t]{2}{*}{$\begin{array}{l}\text { Luk. } \\
\text { 6:6-11 }\end{array}$} & \multirow{2}{*}{$\begin{array}{l}\text { Yesus } \\
\text { Kristus } \\
\text { mengajar } \\
\text { dan } \\
\text { menyem- } \\
\text { buhkan }\end{array}$} & \multirow[t]{2}{*}{$\begin{array}{l}\text { Rumah } \\
\text { Ibadat }\end{array}$} & \multirow{2}{*}{$\begin{array}{l}\text { Orang Farisi } \\
\text { dan ahli } \\
\text { Taurat } \\
\text { sepakat untuk } \\
\text { melakukan } \\
\text { hal yang } \\
\text { buruk kepada }\end{array}$} & & & & Yesus Kristus. \\
\hline & & & & $\begin{array}{c}\text { Luk. } \\
\text { 10:1-20 }\end{array}$ & $\begin{array}{l}\text { Yesus } \\
\text { Kristus } \\
\text { mengutus } \\
\text { ketujuh- }\end{array}$ & $\begin{array}{l}\text { Kota-kota } \\
\text { di Samaria }\end{array}$ & $\begin{array}{l}\text { Murid-murid } \\
\text { telah } \\
\text { menaklukkan } \\
\text { setan dan }\end{array}$ \\
\hline
\end{tabular}


HUPĒRETĒS: Jurnal Teologi dan Pendidikan Kristen 2 no. 2 (2021)

\begin{tabular}{|c|c|c|c|}
\hline & $\begin{array}{l}\text { puluh } \\
\text { murid } \\
\text { dengan } \\
\text { berjalan } \\
\text { berdua-dua } \\
\text { untuk } \\
\text { memberita- } \\
\text { kan injil } \\
\text { dan } \\
\text { melakukan } \\
\text { mujizat } \\
\end{array}$ & & $\begin{array}{l}\text { membawa } \\
\text { berita yang } \\
\text { baik. }\end{array}$ \\
\hline $\begin{array}{c}\text { Luk. } \\
\text { 11:14-23 }\end{array}$ & $\begin{array}{l}\text { Yesus } \\
\text { Kristus } \\
\text { mengusir } \\
\text { roh jahat }\end{array}$ & $\begin{array}{l}\text { Di sebuah } \\
\text { kampung }\end{array}$ & $\begin{array}{l}\text { Orang } \\
\text { Yahudi } \\
\text { menolak Dia }\end{array}$ \\
\hline $\begin{array}{c}\text { Luk. } \\
\text { 12:1-59 }\end{array}$ & $\begin{array}{l}\text { Yesus } \\
\text { Kristus } \\
\text { mengajar } \\
\text { orang } \\
\text { banyak }\end{array}$ & - & $\begin{array}{l}\text { Seeorang dari } \\
\text { orang banyak } \\
\text { tersebut } \\
\text { mereponi } \\
\text { dengan } \\
\text { pertanyaan. } \\
\text { Sehingga } \\
\text { terjadi } \\
\text { diskusi. }\end{array}$ \\
\hline $\begin{array}{c}\text { Luk. } \\
\text { 18:31-34 }\end{array}$ & $\begin{array}{l}\text { Yesus } \\
\text { Kristus } \\
\text { mengajak } \\
\text { murid- } \\
\text { muridnya } \\
\text { berjalan } \\
\text { bersama ke } \\
\text { Yerusalem } \\
\text { dan } \\
\text { memberi- } \\
\text { tahukan } \\
\text { tentang } \\
\text { penderitaan } \\
\text {-Nya }\end{array}$ & - & $\begin{array}{l}\text { Murid-murid } \\
\text { tidak } \\
\text { mengetahui } \\
\text { hal-hal yang } \\
\text { Dia jelaskan. }\end{array}$ \\
\hline $\begin{array}{c}\text { Luk. } \\
\text { 19:1-10 }\end{array}$ & $\begin{array}{l}\text { Isa datang } \\
\text { dan } \\
\text { mengun- } \\
\text { jungi } \\
\text { Zakheus }\end{array}$ & Yerikho & $\begin{array}{l}\text { Zakeus } \\
\text { menerima } \\
\text { dengan } \\
\text { gembira dan } \\
\text { terjadi } \\
\text { transformsi } \\
\text { hidup } \\
\text { Zakheus. }\end{array}$ \\
\hline $\begin{array}{c}\text { Luk. } \\
19: 45-48\end{array}$ & $\begin{array}{l}\text { Yesus } \\
\text { Kristus } \\
\text { menyucikan } \\
\text { bait Allah }\end{array}$ & Yerusalem & $\begin{array}{l}\text { Rakyat } \\
\text { terpikat } \\
\text { kepadaNya } \\
\text { dan ingin } \\
\text { mendengar- } \\
\text { kan Dia }\end{array}$ \\
\hline Luk. & Yesus & Yerusalem & Mereka \\
\hline
\end{tabular}

\begin{tabular}{|c|c|c|c|}
\hline $\begin{array}{l}22: 63 \\
23: 32\end{array}$ & $\begin{array}{l}\text { Kristus } \\
\text { berusaha } \\
\text { meyakinkan } \\
\text { MA, } \\
\text { Pilatus, dan } \\
\text { Herodes } \\
\text { mengenai } \\
\text { diriNya }\end{array}$ & & $\begin{array}{l}\text { semua } \\
\text { menolak Dia. }\end{array}$ \\
\hline $\begin{array}{c}\text { Luk. } \\
24: 36-53\end{array}$ & $\begin{array}{l}\text { Yesus } \\
\text { Kristus } \\
\text { menampak- } \\
\text { kan diri } \\
\text { kepada para } \\
\text { murid dan } \\
\text { mengutus } \\
\text { memberita- } \\
\text { kan injil }\end{array}$ & Yerusalem & $\begin{array}{l}\text { Mereka } \\
\text { melihat Yesus } \\
\text { Kristus, } \\
\text { percaya dan } \\
\text { sujud } \\
\text { menyembah- } \\
\text { Nya }\end{array}$ \\
\hline
\end{tabular}

\section{Analisis Murid Yesus dan Orang Percaya Yesus Kristus menurut Kisah Para Rasul}

Sebelumnya, peneliti memaparkan tentang pola pelayanan misi yang dilakukan oleh Yesus, maka pada bagian ini peneliti memaparkan tentang kelanjutan program misi tersebut yang harus dilakukan oleh para murid dan gereja. Oleh karena itu, pada bagian ini peneliti memaparkan analisis pekerjaan misi yang dilakukan oleh para murid dan gereja yang telah dibangun oleh Yesus melalui pekerjaan Roh Kudus sesuai dengan catatan Lukas dalam Kisah Para Rasul.

\begin{tabular}{|c|c|c|c|}
\hline Nats & Aktivitas & Tempat & $\begin{array}{c}\text { Tanggapan } \\
\text { Orang }\end{array}$ \\
\hline $\begin{array}{l}\text { Kis. } \\
1: 1-28\end{array}$ & $\begin{array}{l}\text { Yesus Kristus } \\
\text { makan } \\
\text { bersama } \\
\text { dengan para } \\
\text { murid dan } \\
\text { memerintah- } \\
\text { kan supaya } \\
\text { tinggal di } \\
\text { Yerusalem }\end{array}$ & Yerusalem & $\begin{array}{l}\text { Mereka } \\
\text { tinggal di } \\
\text { Yerusalem } \\
\text { dan } \\
\text { menantikan } \\
\text { janji Yesus } \\
\text { Kristus serta } \\
\text { memilih } \\
\text { Matias } \\
\text { sebagai ganti } \\
\text { rasul Yudas. }\end{array}$ \\
\hline $\begin{array}{l}\text { Kis. } \\
2: 14- \\
40\end{array}$ & $\begin{array}{l}\text { Petrus } \\
\text { berkhotbah } \\
\text { tentang } \\
\text { injil. }\end{array}$ & Bait Allah & $\begin{array}{l}\text { Mereka } \\
\text { terharu dan } \\
\text { mulai } \\
\text { bertanya- } \\
\text { tanva hal }\end{array}$ \\
\hline
\end{tabular}




\begin{tabular}{|c|c|c|c|c|c|c|c|}
\hline & & & $\begin{array}{l}\text { apakah yang } \\
\text { harus mereka } \\
\text { lakukan? }\end{array}$ & & & & $\begin{array}{l}\text { kepada para } \\
\text { rasul untuk } \\
\text { menerima } \\
\text {.. }\end{array}$ \\
\hline \multirow{2}{*}{$\begin{array}{l}\text { Kis. } \\
2: 41 \\
47\end{array}$} & \multirow[b]{2}{*}{$\begin{array}{l}\text { Jemaat } \\
\text { hidup } \\
\text { bersama } \\
\text { dalam } \\
\text { perseku- } \\
\text { tuan dan } \\
\text { saling } \\
\text { berbagi }\end{array}$} & \multirow[t]{2}{*}{ Yerusalem } & \multirow{2}{*}{$\begin{array}{l}\text { Setiap hari } \\
\text { jumlah } \\
\text { mereka } \\
\text { semakin } \\
\text { bertambah. }\end{array}$} & & & & mujizat. \\
\hline & & & & \multirow[t]{2}{*}{$\begin{array}{l}\text { Kis. } \\
6: 1-7\end{array}$} & \multirow[t]{2}{*}{$\begin{array}{l}\text { Para rasul } \\
\text { memilih } \\
\text { para } \\
\text { pelayan. }\end{array}$} & \multirow[t]{2}{*}{ Yerusalem } & \multirow[t]{2}{*}{$\begin{array}{l}\text { Firman Allah } \\
\text { makin tersebar } \\
\text { dan jumlah } \\
\text { murid makin } \\
\text { banyak dan } \\
\text { sejumlah imam } \\
\text { besar menjadi } \\
\text { percaya. }\end{array}$} \\
\hline \multirow{3}{*}{$\begin{array}{l}\text { Kis. } \\
\text { 3:1:10 }\end{array}$} & \multirow{3}{*}{$\begin{array}{l}\text { Petrus } \\
\text { menyem- } \\
\text { buhkan } \\
\text { orang } \\
\text { lumpuh }\end{array}$} & \multirow[t]{3}{*}{ Bait Allah } & \multirow{3}{*}{$\begin{array}{l}\text { 1. Orang } \\
\text { lumpuh } \\
\text { disembuh- } \\
\text { kan dan } \\
\text { memuji } \\
\text { Allah. } \\
\text { 2. Orang- } \\
\text { orang yang } \\
\text { melihatnya } \\
\text { takjub dan } \\
\text { tercengang. }\end{array}$} & & & & \\
\hline & & & & $\begin{array}{l}\text { Kis. } \\
\text { 8:4-13 }\end{array}$ & $\begin{array}{l}\text { Filipus } \\
\text { menjelajah } \\
\text { samaria, } \\
\text { memberitak } \\
\text { an injil dan } \\
\text { melakukan } \\
\text { tanda. }\end{array}$ & Samaria & $\begin{array}{l}\text { Banyak orang } \\
\text { di Samaria } \\
\text { percaya } \\
\text { terhadap injil } \\
\text { yang } \\
\text { diberitakan } \\
\text { Filipus dan } \\
\text { memberi diri } \\
\text { dibaptis (12) }\end{array}$ \\
\hline & & & & \multirow{3}{*}{$\begin{array}{c}\text { Kis. } \\
8: 26 \\
39\end{array}$} & \multirow{3}{*}{$\begin{array}{l}\text { Filipus } \\
\text { diperintah- } \\
\text { kan oleh } \\
\text { malaikat } \\
\text { Tuhan } \\
\text { untuk pergi } \\
\text { ke jalur } \\
\text { Gaza dan } \\
\text { bertemu } \\
\text { sida-sida } \\
\text { Etiopia dan } \\
\text { memberita- } \\
\text { kan injil } \\
\text { kepada } \\
\text { mereka. }\end{array}$} & \multirow[t]{3}{*}{ Jalur Gaza } & \multirow{3}{*}{$\begin{array}{l}\text { Orang Etiopia } \\
\text { itu menjadi } \\
\text { percaya dan } \\
\text { memberi diri } \\
\text { dibaptis. }\end{array}$} \\
\hline $\begin{array}{l}\text { Kis. } \\
3: 11 \\
4: 4\end{array}$ & $\begin{array}{l}\text { Petrus } \\
\text { berkhotbah } \\
\text { di serambi } \\
\text { salomo. }\end{array}$ & $\begin{array}{l}\text { Serambi } \\
\text { Salomo }\end{array}$ & 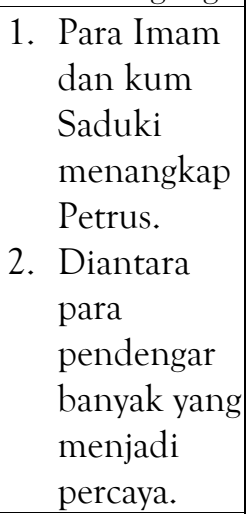 & & & & \\
\hline \multirow[t]{2}{*}{$\begin{array}{l}\text { Kis. } \\
4: 23 \\
31\end{array}$} & \multirow[t]{2}{*}{$\begin{array}{l}\text { Jemaat } \\
\text { berdoa }\end{array}$} & \multirow[t]{2}{*}{ Yerusalem } & \multirow{2}{*}{$\begin{array}{l}\text { Mereka penuh } \\
\text { dengan Roh } \\
\text { Kudus dan } \\
\text { Jemaat } \\
\text { semakin berani } \\
\text { memberitakan } \\
\text { firman Allah. }\end{array}$} & & & & \\
\hline & & & & \multirow[t]{2}{*}{$\begin{array}{l}\text { Kis. } \\
\text { 9:1-25 }\end{array}$} & \multirow{2}{*}{$\begin{array}{l}\text { Yesus } \\
\text { Kristus } \\
\text { menampak } \\
\text { kan diri } \\
\text { kepada } \\
\text { Saulus }\end{array}$} & \multirow[t]{2}{*}{$\begin{array}{l}\text { Jalan ke } \\
\text { Damsyik }\end{array}$} & $\begin{array}{l}\text { 1. Saulus } \\
\text { bertobat dan } \\
\text { menjadi } \\
\text { percaya }\end{array}$ \\
\hline \multirow[t]{2}{*}{$\begin{array}{l}\text { Kis. } \\
4: 32 \\
37\end{array}$} & \multirow{2}{*}{$\begin{array}{l}\text { Jemaat } \\
\text { berkumpul, } \\
\text { sehati dan } \\
\text { sejiwa dan } \\
\text { saling } \\
\text { bersaksi } \\
\text { mengenai } \\
\text { kebangkitan } \\
\text { Yesus } \\
\text { Kristus. } \\
\end{array}$} & \multirow[t]{2}{*}{ Yerusalem } & \multirow[t]{2}{*}{$\begin{array}{l}\text { Mereka } \\
\text { menjual } \\
\text { miliknya dan } \\
\text { ditaruh } \\
\text { dihadapan } \\
\text { kaki para rasul. }\end{array}$} & & & & $\begin{array}{l}\text { kepada Yesus } \\
\text { Kristus. } \\
\text { 2. Orang-orang } \\
\text { Yahudi } \\
\text { berusaha } \\
\text { membunuh } \\
\text { Saulus. }\end{array}$ \\
\hline & & & & \multirow[t]{2}{*}{$\begin{array}{l}\text { Kis. } \\
9: 26- \\
31\end{array}$} & \multirow{2}{*}{$\begin{array}{l}\text { Saulus } \\
\text { mengga- } \\
\text { bungkan } \\
\text { diri dengan } \\
\text { jemaat. } \\
\text { Barnabas }\end{array}$} & \multirow[t]{2}{*}{ Yerusalem } & \multirow{2}{*}{$\begin{array}{l}\text { Jemaat hidup } \\
\text { damai dan } \\
\text { jumlah } \\
\text { mereka } \\
\text { bertambah } \\
\text { banyak. }\end{array}$} \\
\hline $\begin{array}{l}\text { Kis. } \\
5: 12 \\
16\end{array}$ & $\begin{array}{l}\text { Para rasul } \\
\text { mengadakan } \\
\text { mujizat }\end{array}$ & $\begin{array}{l}\text { Serambi } \\
\text { Salomo }\end{array}$ & $\begin{array}{l}\text { Banyak orang } \\
\text { berduyun- } \\
\text { duyun datang }\end{array}$ & & & & \\
\hline
\end{tabular}


HUPËRETĒS: Jurnal Teologi dan Pendidikan Kristen 2 no. 2 (2021)

\begin{tabular}{|c|c|c|c|c|c|c|c|}
\hline & $\begin{array}{l}\text { menerima } \\
\text { Salus }\end{array}$ & & & & & & $\begin{array}{l}\text { memuliakan } \\
\text { Allah. }\end{array}$ \\
\hline & $\begin{array}{l}\text { menjadi } \\
\text { mitra } \\
\text { pelayanan. }\end{array}$ & & & \multirow[t]{2}{*}{$\begin{array}{l}\text { Kis. } \\
\text { 14:1-7 }\end{array}$} & \multirow{2}{*}{$\begin{array}{l}\text { Paulus dan } \\
\text { Barnabas } \\
\text { tinggal } \\
\text { beberapa } \\
\text { hari dan } \\
\text { mengajar } \\
\text { jemaat }\end{array}$} & \multirow[t]{2}{*}{ Ikonium } & \multirow{2}{*}{$\begin{array}{l}\text { Tuhan } \\
\text { menguatkan } \\
\text { berita kasih } \\
\text { karunia. } \\
\text { Tetapi orang- } \\
\text { orang Yahudi } \\
\text { menyiksa } \\
\text { kedua rasul } \\
\text { tersebut. }\end{array}$} \\
\hline \multirow[t]{2}{*}{$\begin{array}{l}\text { Kis. } \\
9: 32- \\
43\end{array}$} & \multirow{2}{*}{$\begin{array}{l}\text { Petrus } \\
\text { menyem- } \\
\text { buhkan } \\
\text { orang sakit } \\
\text { dan } \\
\text { membang- } \\
\text { kitkan } \\
\text { orang mati }\end{array}$} & \multirow[t]{2}{*}{$\begin{array}{l}\text { Lida dan } \\
\text { Yope }\end{array}$} & \multirow[t]{2}{*}{$\begin{array}{l}\text { Banyak orang } \\
\text { berbalik } \\
\text { kepada } \\
\text { Tuhan dan } \\
\text { menjadi } \\
\text { percaya. }\end{array}$} & & & & \\
\hline & & & & \multirow{2}{*}{$\begin{array}{c}\text { Kis. } \\
\text { 14-19. } \\
21\end{array}$} & \multirow{2}{*}{$\begin{array}{l}\text { Paulus } \\
\text { memberita- } \\
\text { kan injil } \\
\text { dikota-kota. }\end{array}$} & \multirow{2}{*}{$\begin{array}{l}\text { Memper- } \\
\text { oleh } \\
\text { banyak } \\
\text { murid. }\end{array}$} & \multirow[t]{2}{*}{ Derbe } \\
\hline \multirow{2}{*}{$\begin{array}{l}\text { Kis. } \\
10: 1- \\
48\end{array}$} & \multirow[b]{2}{*}{$\begin{array}{l}\text { Petrus } \\
\text { mendapat } \\
\text { penglihatan } \\
\text { bahwa } \\
\text { makanan } \\
\text { haram } \\
\text { boleh } \\
\text { dimakan. } \\
\text { Dan dia } \\
\text { memberita- } \\
\text { kan injil } \\
\text { kepada } \\
\text { Kornelius. }\end{array}$} & \multirow[t]{2}{*}{ Kaisarea } & \multirow{2}{*}{$\begin{array}{l}\text { Kornelius } \\
\text { dan seisi } \\
\text { keluarga } \\
\text { menjadi } \\
\text { percaya. }\end{array}$} & & & & \\
\hline & & & & \multirow[t]{2}{*}{$\begin{array}{l}\text { Kis. } \\
14: 21 \\
b-28\end{array}$} & \multirow{2}{*}{$\begin{array}{l}\text { Paulus } \\
\text { kembali ke } \\
\text { Listra, } \\
\text { Ikonium, } \\
\text { Dan } \\
\text { Antiokhia } \\
\text { untuk } \\
\text { menguat- } \\
\text { kan jemaat } \\
\text { serta } \\
\text { membentuk } \\
\text { penatua di } \\
\text { jemaat } \\
\text { setempat. } \\
\end{array}$} & \multirow[t]{2}{*}{ Anthiokhia } & \multirow[t]{2}{*}{$\begin{array}{l}\text { Firman Allah } \\
\text { tersebar ke } \\
\text { seluruh } \\
\text { Pisidia dan } \\
\text { pamfilia. }\end{array}$} \\
\hline \multirow[t]{2}{*}{$\begin{array}{l}\text { Kis. } \\
\text { 11:19. } \\
21\end{array}$} & \multirow{2}{*}{$\begin{array}{l}\text { Orang } \\
\text { percaya } \\
\text { menyebar } \\
\text { dan } \\
\text { memberita- } \\
\text { kan injil } \\
\text { kepada } \\
\text { orang-orang } \\
\text { Yunani. }\end{array}$} & \multirow[t]{2}{*}{ Anthiokhia } & \multirow{2}{*}{$\begin{array}{l}\text { Sejumlah } \\
\text { besar orang } \\
\text { menjadi } \\
\text { percaya. }\end{array}$} & & & & \\
\hline & & & & $\begin{array}{l}\text { Kis. } \\
16: 4 \\
12\end{array}$ & $\begin{array}{l}\text { Paulus } \\
\text { memperoleh } \\
\text { penglihatan } \\
\text { untuk } \\
\text { menyeberang } \\
\text { ke }\end{array}$ & Troas & $\begin{array}{l}\text { Paulus } \\
\text { menyeberang } \\
\text { dan sampai di } \\
\text { Makedonia. }\end{array}$ \\
\hline \multirow{2}{*}{$\begin{array}{l}\text { Kis. } \\
13: 4 \\
12\end{array}$} & \multirow[b]{2}{*}{$\begin{array}{l}\text { Saulus dan } \\
\text { Barnabas } \\
\text { mengelilingi } \\
\text { pulau Pafos } \\
\text { dan melawan } \\
\text { tukang sihir. }\end{array}$} & \multirow[t]{2}{*}{ Salamis } & \multirow[b]{2}{*}{$\begin{array}{l}\text { Ahli sihir } \\
\text { menjadi buta. } \\
\text { Gubernur } \\
\text { setempat } \\
\text { menjadi } \\
\text { takjub } \\
\text { dengan ajaran } \\
\text { Tuhan. }\end{array}$} & & Makedonia. & & \\
\hline & & & & \multirow[t]{2}{*}{$\begin{array}{c}\text { Kis. } \\
16: \\
13-40\end{array}$} & \multirow{2}{*}{$\begin{array}{l}\text { Paulus } \\
\text { menyusuri } \\
\text { sungai dan } \\
\text { menemukan } \\
\text { tempat } \\
\text { bersembah- } \\
\text { yang bagi } \\
\text { orang } \\
\text { Yahudi dan } \\
\text { berbicara } \\
\text { kepada para } \\
\text { perempuan. } \\
\text { Paulus juga } \\
\text { mengeluar- } \\
\text { kan roh } \\
\text { tenung dari } \\
\text { penyihir. } \\
\end{array}$} & \multirow[t]{2}{*}{ Filipi } & \multirow[t]{2}{*}{$\begin{array}{l}\text { Kepala } \\
\text { penjara dan } \\
\text { seisi } \\
\text { rumahnya } \\
\text { menjadi } \\
\text { percaya dan } \\
\text { memberi diri } \\
\text { dibaptis. }\end{array}$} \\
\hline $\begin{array}{l}\text { Kis. } \\
13: 13 \\
49\end{array}$ & $\begin{array}{l}\text { Paulus } \\
\text { berkotbah } \\
\text { di rumah } \\
\text { ibadat } \\
\text { selama } \\
\text { beberapa } \\
\text { hari tentang } \\
\text { injil. }\end{array}$ & Pisidia & $\begin{array}{l}\text { Orang-orang } \\
\text { Yahudi yang } \\
\text { takut Tuhan } \\
\text { dan orang- } \\
\text { orang yang } \\
\text { tidak } \\
\text { mengenal } \\
\text { Allah } \\
\text { bergembira } \\
\text { dan }\end{array}$ & & & & \\
\hline
\end{tabular}


HUPĒRETĒS: Jurnal Teologi dan Pendidikan Kristen 2 no. 2 (2021)

\begin{tabular}{|c|c|c|c|}
\hline & $\begin{array}{l}\text { Rupanya hal } \\
\text { tersebut } \\
\text { menjadikan } \\
\text { dia } \\
\text { dipenjara. } \\
\text { Namun } \\
\text { oleh kuasa } \\
\text { Roh kudus, } \\
\text { dia dibebas- } \\
\text { kan dan } \\
\text { memberita- } \\
\text { kan injil } \\
\text { kepada } \\
\text { kepala } \\
\text { penjara. }\end{array}$ & & \\
\hline $\begin{array}{l}\text { Kis. } \\
17: 1-8\end{array}$ & $\begin{array}{l}\text { Paulsu } \\
\text { mengajar di } \\
\text { rumah } \\
\text { ibadat } \\
\text { selama tiga } \\
\text { minggu } \\
\text { berturut- } \\
\text { turut } \\
\text { mengenai } \\
\text { injil. }\end{array}$ & Tesalonika & $\begin{array}{l}\text { 1. Sejumlah } \\
\text { besar orang } \\
\text { Yunani } \\
\text { menjadi } \\
\text { percaya dan } \\
\text { mengikuti } \\
\text { Paulus. } \\
\text { 2. Orang-orang } \\
\text { Yahudi iri } \\
\text { hati dan } \\
\text { mengadakan } \\
\text { keributan di } \\
\text { Tesalonika. }\end{array}$ \\
\hline $\begin{array}{c}\text { Kis. } \\
17: 10 \\
15\end{array}$ & \begin{tabular}{l|} 
Paulus \\
melarikan \\
diri ke Berea \\
dan \\
memberita- \\
kan injil dan \\
mengajar \\
ditempat \\
ibadat orang \\
Yahudi.
\end{tabular} & Berea & $\begin{array}{l}\text { Banyak dari } \\
\text { antara orang } \\
\text { Yahudi } \\
\text { menjadi } \\
\text { percaya, dan } \\
\text { juga ada } \\
\text { beberapa } \\
\text { orang Yunani } \\
\text { yang menjadi } \\
\text { percaya. }\end{array}$ \\
\hline $\begin{array}{l}\text { Kis. } \\
17: 18 \\
34\end{array}$ & $\begin{array}{l}\text { Paulus mem- } \\
\text { beritakan } \\
\text { injil ke } \\
\text { Athena. } \\
\text { Memulai } \\
\text { dengan } \\
\text { masalah } \\
\text { penciptaan } \\
\text { sampai pada } \\
\text { kisah tentang } \\
\text { Yesus } \\
\text { Kristus. }\end{array}$ & Athena & $\begin{array}{l}\text { Beberapa } \\
\text { orang } \\
\text { menggabung- } \\
\text { kan diri } \\
\text { dengan } \\
\text { Paulus dan } \\
\text { menjadi } \\
\text { percaya. }\end{array}$ \\
\hline $\begin{array}{l}\text { Kis. } \\
18: 1- \\
16\end{array}$ & $\begin{array}{l}\text { Paulus mem- } \\
\text { beritakan } \\
\text { injil }\end{array}$ & Korintus & $\begin{array}{l}\text { Kepala rumah } \\
\text { ibadat orang } \\
\text { Yahudi }\end{array}$ \\
\hline
\end{tabular}

\begin{tabular}{|c|c|c|c|}
\hline & $\begin{array}{l}\text { berbicara di } \\
\text { rumah ibadat } \\
\text { orang } \\
\text { Yahudi dan } \\
\text { tinggal } \\
\text { berxama- } \\
\text { sama dengan } \\
\text { Akwila serta } \\
\text { melakukan } \\
\text { pekerjaan } \\
\text { bersama- } \\
\text { sama. }\end{array}$ & & $\begin{array}{l}\text { menjadi } \\
\text { percaya. }\end{array}$ \\
\hline $\begin{array}{c}\text { Kis. } \\
19: 1- \\
11\end{array}$ & $\begin{array}{l}\text { Paulus } \\
\text { menjelajahi } \\
\text { pedalaman } \\
\text { Efesus, } \\
\text { memberita- } \\
\text { kan injil dan } \\
\text { mengajar di } \\
\text { ruang kuliah } \\
\text { Tiranus } \\
\text { selama dua } \\
\text { tahun. }\end{array}$ & Efesus & $\begin{array}{l}\text { Sebagian } \\
\text { orang } \\
\text { menjadi } \\
\text { percaya dan } \\
\text { menerima } \\
\text { kuasa } \\
\text { melakukan } \\
\text { mujizat. }\end{array}$ \\
\hline $\begin{array}{c}\text { Kis. } \\
22: 1: 2 \\
2\end{array}$ & $\begin{array}{l}\text { Paulus } \\
\text { memper- } \\
\text { tanggung- } \\
\text { jawakan } \\
\text { tuduhan } \\
\text { atasnya. } \\
\text { Dalam } \\
\text { pertanggung- } \\
\text { jawaban } \\
\text { tersebut dia } \\
\text { mencerita- } \\
\text { kan kembali } \\
\text { kisah } \\
\text { panggilannya }\end{array}$ & Yerusalem & $\begin{array}{l}\text { Rakyat } \\
\text { semakin } \\
\text { menolak } \\
\text { paulus dan } \\
\text { hendak } \\
\text { membunuh } \\
\text { Paulus. }\end{array}$ \\
\hline $\begin{array}{c}\text { Kis. } \\
26: 1- \\
32\end{array}$ & $\begin{array}{l}\text { Paulus } \\
\text { memper- } \\
\text { tanggung- } \\
\text { jawabkan } \\
\text { tuduhan } \\
\text { atasnya } \\
\text { kepada } \\
\text { Agripa. } \\
\text { Dalam } \\
\text { pertanggung- } \\
\text { jawaban } \\
\text { tersebut dia } \\
\text { mencerita- } \\
\text { kan kembali } \\
\text { kisah } \\
\text { panggilannya }\end{array}$ & Kaisarea. & $\begin{array}{l}\text { Agripa } \\
\text { hampir } \\
\text { percaya dan } \\
\text { mejadi } \\
\text { pengikut } \\
\text { Kristen } \\
\text { (sebutan } \\
\text { untuk orang } \\
\text { pecaya pada } \\
\text { masa itu). }\end{array}$ \\
\hline
\end{tabular}




\begin{tabular}{|c|c|c|c|}
\hline & \begin{tabular}{l|} 
serta \\
mengajak \\
Agripa untuk \\
percaya \\
kepada Yesus \\
Kristus.
\end{tabular} & & \\
\hline $\begin{array}{c}\text { Kis. } \\
28: 1- \\
10\end{array}$ & $\begin{array}{l}\text { Paulus } \\
\text { menyembuh- } \\
\text { kan } \\
\text { gubernur } \\
\text { Pubius serta } \\
\text { beberapa } \\
\text { warga sekitar. }\end{array}$ & Malta & $\begin{array}{l}\text { Rakyat } \\
\text { menyambut } \\
\text { baik Paulus } \\
\text { dan } \\
\text { memelihara } \\
\text { kehidupan } \\
\text { Paulus. }\end{array}$ \\
\hline $\begin{array}{c}\text { Kis. } \\
28: 17- \\
29\end{array}$ & \begin{tabular}{l|} 
Paulus \\
berdiskusi \\
dengan \\
orang-orang \\
Yahudi \\
mengenai \\
hukum \\
Musa yang \\
merujuk \\
kepada \\
Yesus \\
Kristus.
\end{tabular} & Roma & $\begin{array}{l}\text { Sebagian } \\
\text { menjadi } \\
\text { percaya dan } \\
\text { sebagian tetap } \\
\text { tidak percaya. }\end{array}$ \\
\hline $\begin{array}{c}\text { Kis. } \\
\text { 28:30- } \\
31\end{array}$ & $\begin{array}{l}\text { Paulus } \\
\text { memberita- } \\
\text { kan injil } \\
\text { kerajaan } \\
\text { Allah } \\
\text { dengan } \\
\text { bebas. }\end{array}$ & Roma & $\begin{array}{l}\text { Banyak orang } \\
\text { menerima } \\
\text { dan datang } \\
\text { kepadanya } \\
(30 \text { b) }\end{array}$ \\
\hline
\end{tabular}

Prinsip teologis yang dapat dipahami dari kebenaran tersebut adalah, pemberitaan injil tidak diperuntukkan bagi budaya tertentu, melainkan juga kepada segala budaya bangsabangsa. Bangsa-bangsa dengan aneka ragam budaya berhak mendapatkan pemberitaan injil Allah. Pada dasarnya Allah menginginkan segala bangsa menyembah Dia. Masing-masing bangsa dengan budayanya masing-masing akan menyembah Allah dan akan menghasilkan harmonisasi budaya yang sangat indah. Masingmasing lidah dengan bahasanya akan mengagungkan keselamatan dari Allah.

Dalam Injil Matius 28:19 dicatatkan suatu perintah tegas, "Pergilah jadikanlah semua bangsa muridKu." Dalam Bahasa Yunani, kata

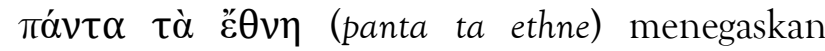
bahwa Yesus memerintahkan para murid memuridkan orang-orang yang bukan hanya pada golongan Yahudi, melainkan orang-orang asing. ${ }^{14}$ Dalam Perjanjian Baru, penggunaan kata $\check{\varepsilon} \theta v \eta$ (ethne) berhubungan dengan identitas yang disematkan. Artinya, ketika penulis Injil Matius tidak menggunakan kata kata $\lambda \alpha o$ s (laos), melainkan kata $\check{\varepsilon} \theta v \eta$ (ethne) yang menekankan pada sekelompok orang dengan budaya dan religi yang berbeda dengan orang-orang Yahudi. ${ }^{15}$

Schnabel mencatatkan tujuan misi Paulus adalah sebagai berikut: Pertama, Paulus tahu bahwa dirinya dipanggil untuk memberikan pesan Yesus Kristus. Ia memperkenalkan diri kepada orang Kristen di kota Roma dengan perkataan, "Dari Paulus, hamba Kristus Yesus, yang dipanggil menjadi rasul dan dikaruniakan untuk memberitakan Injil Allah" (Rm.1:1). Dalam 1 Korintus 2:2, ia menjelaskan bahwa sebagai misionaris perintis, ia memfokuskan khotbahnya pada "Yesus Kristus, yaitu Dia yang disalibkan."

Kedua, Paulus tahu bahwa dirinya secara khusus dipanggil untuk memberitakan Injil Yesus Kristus kepada bangsa-bangsa lainnya, yaitu penganut politeisme yang menyembah ilahilah lain. Ia mengingatkan orang Kristen di Roma tentang fakta bahwa ia "berhutang baik kepada orang Yunani, maupun kepada orang bukan Yunani, baik kepada orang terpelajar, maupun orang tidak terpelajar" (Rm. 1:4). Namun, Paulus berkhotbah di hadapan orang Yahudi. Ia mengingatkan orang Kristen di Korintus bahwa pemberitaannya tentang Yesus sebagai Mesias yang disalibkan, Juruselamat, dan Tuhan merupakan "suatu batu sandungan untuk orang-orang Yahudi dan suatu kebodohan untuk orang-orang bukan Yahudi" (1 Kor. 1:23). Paulus menyatakan bahwa ia "mempunyai keyakinan yang kokoh dalam Injil, karena Injil adalah kekuatan Allah yang menyelamatkan setiap orang yang percaya, pertama-tama orang Yahudi, tetapi juga orang Yunani” (Rm. 1:16).

${ }^{14}$ Barbara Friberg, Timothy Friberg, and Neva F. Miller, Analytical Lexicon of The New Testament (Grand Rapids: Baker Books, 2000).

${ }^{15}$ Wilbur F. Gingrich, Shorter Lexicon of the Greek New Testament, ed. Frederick W Danker, 2nd ed. (Chicago: The University of Chicago Press, 2007), 55. 
Ketiga, tujuan Paulus adalah menjangkau sebanyak mungkin orang. Ia ingin memberitakan "baik kepada orang Yunani, maupun kepada orang bukan Yunani, baik kepada orang terpelajar, maupun kepada orang tidak terpelajar" (Rm. 1:14). Ia memberitakan kabar baik tentang Yesus Kristus "dari Yerusalem sampai ke Ilirikum” (Rm. 15:19). Ia terlibat dalam pekerjaan misi di Yudea dan Arabia. Ia bergerak ke utara untuk menginjilke Siprus, di Provinsi Galatia dan Pamfilia di bagian tengah dan selatan Asia Kecil. Ketika rencananya untuk memberitakan Injil di Provinsi Asia, provinsi paling barat di Asia Kecil, tidak dapat dilaksanakan, ia bergerak lebih jauh ke barat menuju Eropa dan memberitakan Injil di Makedonia dan Akhaya. Kemudian, ia bergerak lagi ke timur untuk memberitakan Injil di Provinsi Asia, mencapai tujuan yang belum terjangkau sebelumnya. Karena ia sekarang "tidak lagi mempunyai tempat kerja di daerah ini," Paulus berencana mengunjungi kota Roma dan dari sana menjangkau Spanyol (Rm. 15:23. 24). Perjalanannya secara geografis menggambarkan setengah lingkaran atas dari Yerusalem melalui Siria, Asia Kecil, Eropa, dan Roma ke Spanyol.

Keempat, Paulus berusaha menuntun setiap orang untuk percaya kepada satu Allah yang benar dan kepada Yesus Kristus, Sang Mesias, Juruselamat dan Tuhan. Itu berarti orang Yahudi harus mengakui bahwa Yesus, pengkhotbah dari Nazaret yang disalibkan, sungguh-sungguh adalah Mesias yang dijanjikan. Mereka juga harus mengakui bahwa kematianNya merupakan jawaban puncak Allah terhadap masalah dosa manusia yang tidak bisa diselesaikan dengan tuntas melalui perjanjian Allah dan Abraham atau hukum Taurat Musa. Mereka pun harus mengakui bahwa Dia dibangkitkan dari antara orang mati sebagai pembuktian misi dan khotbah-Nya. Bangsabangsa lain harus berpaling dari ilah tradisional mereka kepada Allah Israel, meninggalkan kuilkuil berhala dengan ritual mereka untuk melayani satu Allah yang hidup dan yang benar, percaya kepada Yesus yang menyelamatkan orang berdosa dari murka Allah, menerima penebusan melalui kematian Yesus di kayu salib, mengizinkan hidup mereka dibentuk oleh Kitab Suci Yahudi dan ajaran Yesus dan rasul-rasul, serta menantikan kedatangan Yesus Kristus (1 Tes. 1:9-10;1 Kor. 1:18-2:5).

Kelima, Paulus mendirikan gereja-gereja baru, komunitas para pengikut Yesus Kristus baik orang Yahudi maupun non-Yahudi, laki-laki maupun perempuan, orang merdeka maupun budak dan mengajar orang yang baru percaya tentang firman Allah, ajaran Yesus, dan pentingnya Injil untuk kehidupan sehari-hari. Paulus menjelaskan aspek pekerjaan misinya mengatakan bahwa dia telah menjadi pelayan jemaat itu sesuai dengan tugas yang dipercayakan Allah kepadanya untuk meneruskan firman-Nya dengan sepenuhnya kepada orang percaya, yaitu rahasia yang tersembunyi dari abad ke abad dan dari turunan ke turunan, tetapi yang sekarang dinyatakan kepada orang-orang kudus-Nya. Kepada mereka Allah mau memberitahukan, betapa kaya dan mulianya rahasia itu di antara bangsa-bangsa lain, yaitu: Kristus ada di tengahtengah orang percaya. ${ }^{16}$

Gereja sebagai komunitas yang dipakai Allah dalam memberitakan terang kepada bangsabangsa harus bergiat dalam pekerjaan misi Allah. Perubahan budaya pengembangan gereja yang cenderung mengarah ke dalam (internal) menjadikan gereja kurang memperhatikan pekerjaan misi bagi bangsa-bangsa. Dampaknya adalah gereja tidak lagi terlibat dalam kegiatan misi yang ditandai ketiadaan departemen atau bidang misi di gereja tersebut. Jika hal tersebut dibiarkan, maka jumlah gereja akan terus menerus mengalami penurunan dan pada akhirnya dimungkinkan ditutup secara permanen. Orang percaya masa kini harus berkaca pada peristiwa sejarah gereja, dimana wilayah dengan mayoritas kekristenan seperti Asia Kecil - Turki, hampir tidak ditemukan lagi sisa-sisa keberadaan gereja. Hal ini terjadi bukan karena adanya invasi dari kepercayaan lainnya, melainkan semangat penginjilan yang tidak dijalankan sebagaimana mestinya sehingga berangsur-angsur mengalami penyusutan.

${ }^{16}$ Eckhard J Schnabel, Rasul Paulus Sang Misionaris: Perjalanan, Strategi dan Metode Misi Rasul Paulus (Yogyakarta: Andi, 2014), 14-16. 
Ada beberapa gereja yang menjaga warisan tradisi gereja mula-mula. Sakramen atau ordonansi dilaksanakan dengan sangat ketat dan menjadi nilai-nilai utama bagi gereja tersebut. Bagaimana dengan pelaksanaan pemberitaan injil yang seharusnya dilakukan? Salah satu tradisi yang paling penting dalam Perjanjian Baru, khususnya kitab Kisah Para Rasul adalah pergerakan gereja dalam pemberitaan injil. Faktanya, beberapa teolog meyakini hadirnya jemaat di Roma adalah akibat adanya migrasi orang percaya setelah peristiwa pencurahan Roh Kudus (Kis. 2:1-13) ke Roma dan memberitakan injil di sana sampai terbentuk jemaaat Roma. ${ }^{17}$

Pekerjaan misi bagi bangsa-bangsa harus didasari pada teologi misi yang alkitabiah. Teologi misi seperti sebuah mesin kapal yang menggerakkan pekerjaan misi yang diberikan Allah. ${ }^{18}$ Tanpa didasari teologi yang alkitabiah, pekerjaan misi tidak akan memiliki dampak yang signifikan. Pentingnya teologi misi yang alkitabiah adalah memberikan arahan dan pedoman pelaksanaan dan sasaran misi yang sedang dilakukan oleh gereja. Oleh karena itu, orang percaya perlu memperhatikan kembali teologi yang mendasari mereka dalam menjalankan misi Allah.

Misi dalam pengertian teologi Kristen adalah suatu tindakan dari anggota gereja yang melangkah keluar melewati batas komunitas mereka untuk memproklamirkan iman kepada Yesus melalui perkataan dan tindakan mereka kepada orang-orang yang tidak percaya dengan tujuan terjadi transformasi iman kepada Yesus melalui karya Roh Kudus. Kegiatan misi tersebut merupakan bentuk ketundukan pada Amanat Agung. Misi merupakan program kerja Allah mengutus gereja agar menjadi saksi bagi dunia.

Apakah arti teologi misi? Dalam pengertian sederhana teologi misi diartikan sebagai seperangkat motif yang melatarbelakangi pelaksanaan misi. Seperangkat motif tersebut

${ }^{17}$ Douglas J. Moo, "The Epistle to The Romans," in The New International Commentary of the New Testament (Grand Rapids: William B. Eerdmans Publishing Company, 2015), 4.

${ }^{18}$ Gailyn Van. Rheenen and Anthony Parker, Missions: Biblical Fondation and Contemporaries Starategies (Grand Rapids: Zondervan, 2014). mencakup prinsip tafsir terhadap teks alkitab terkait misi, metodologi pelaksanaan misi, strategi pelaksanaan misi serta tujuan utama pelaksanaan misi. Pentingnya teologi misi adalah untuk mengoreksi konsep misi yang tidak matang. Ada kecenderungan pelaksanaan misi didasarkan pada satu nats tertentu tanpa memperhatikan keseluruhan kitab (sinkronik kanonnik). Hal ini menyebabkan presuposisi terkait dengan misi dibangun berdasarkan penafsiran nats yang terisolir. Misal, preposisi misi yang hanya dibangun dari nats Amanat Agung (Mat. 28:19-20) dan narasi kisah Yunus akan memberikan kesan bahwa gereja yang bertanggungjawab penuh terhadap kegiatan misi. Sesungguhnya, melalui penyelidikan yang komprehensif terhadap seluruh kitab kanonik memberikan pemahaman bahwa Allah adalah inisiator, perencana, pengelola dan pembuat hasil kegiatan misi (misio dei).

Alkitab adalah sumber utama dalam membangun teologi misi. Dalam membangun teologi misi yang bersumber dari alkitab, penafsir perlu mengembangan prinsip hermenetik dalam berteologi. Penafsir dituntut mengobservasi natsnats alkitab secara menyeluruh kemudian memperhatikan tema, tujuan, bentuk atau desain misi yang tengah dibangun oleh penulis kitab. Untuk menolong kita mengembangkan prinsip hermeneutika, Van Engen menyarankan kita melandaskan teologi misi kita pada aneka ragam tema dan motif, masing-masing dalam konteks historisnya.

Dalam melaksanakan misi Allah, perlu landasan alkitab yang kokoh. Beberapa hal yang akan ditempuh oleh peneliti dalam menerapkan misi yang alkitabiah adalah sebagai berikut;

Pertama, memahami hati Allah melalui ajaran dan doa. Alkitab adalah Firman Allah dan isi hati Allah yang hendak disampaikan kepada manusia. Peneliti akan secara terus menerus mempelajari firman Allah dan berdoa kiranya Allah memberikan penerangan kepada peneliti agar mampu menjalankan misi sesuai dengan penyataan firman Allah. Doa menjadi kekuatan bagi peneliti dalam menetapkan sasaran dan menyusun strategi dalam pemberitaan injil. Peneliti harus memulai dari diri sendiri sebelum melangkap pada tahap selanjutnya. 
Kedua, bekerjasama dengan jemaat. Dalam pelaksanaan misi perlu adanya kerjasama dengan gereja lokal. Peneliti memuridkan, mendorong dan memperlengkapi jemaat lokal agar terlibat dalam kegiatan misi. Jemaat lokal merupakan aset berharga karena mereka hidup ditengahtengah masyarakat yang menjadi sasaran misi. Dengan melibatkan jemaat lokal dalam kegiatan misi, maka akan membangun identitas jemaat lokal (gereja) yang misioner.

Ketiga, mengutus dan mendukung pelaksanaan misi. Selain melibatkan jemaat lokal, peneliti juga mengupayakan dapat mengutus dan mendukung pelaksanaan misi di tempat yang berbeda. Tujuan program ini adalah untuk memperluas jangkauan misi kepada kaum mayoritas maupun kaum yang belum terjangkau injil. Jemaat dapat memakai kearifan lokal (ekonomi dan sosial) sebagai sarana berbaur dengan masyarakat. Pola pelaksanaan misi yang direncanakan oleh peneliti berupa siklus sebagai berikut;

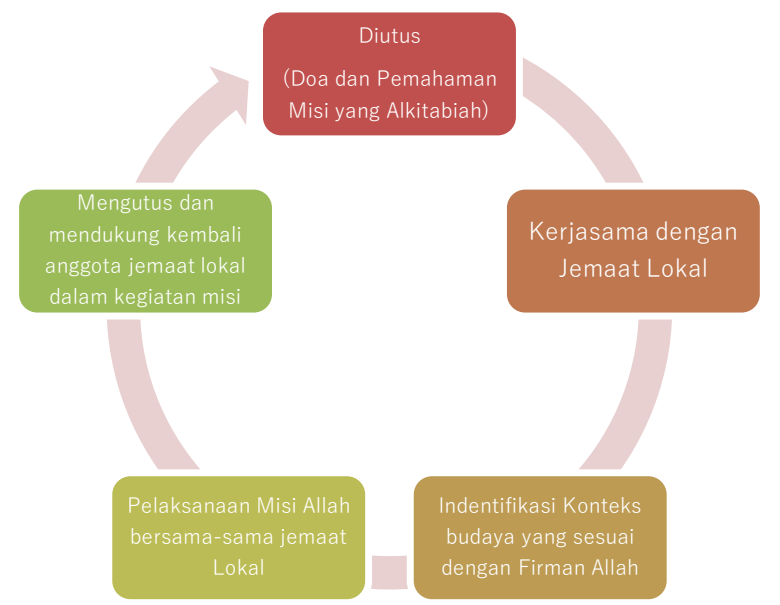

Jadi, dalam konteks pelayanan misi di Indonesia dengan keragaman budaya maka ada beberapa model yang disarankan oleh peneliti antara lain: pertama, melakukan kontekstualisasi misi, bukan kontekstualisasi teologi. Seorang pemberita injil harus memiliki keyakinan teologi yang konservatif. Teologi alkitabiah akan tetap relevan sepanjang abad. Dalam upaya menyikapi perubahan budaya masyarakat dapat dilakukan dengan menyesuaikan model pelayanan sesuai dengan budaya setempat. Misalnya untuk suku Jawa, maka dapat dibuat model pelayanan dengan media wayang kulit atau tembang macapat. Seorang pemberita injil tidak boleh mengkontekstualisasikan teologi karena dapat mengubah nilai-nilai yang terkandung dalam injil.

Kedua, membuat model pelayanan yang mampu menjangkau segala budaya (church for all nations). Mengingat adanya migrasi yang tinggi di kalangan masyarakat di Indonesia, maka gereja perlu memikirkan sebuah model pelayanan yang dapat menjangkau seluruh budaya lokal. Misal, jika dalam sebuah gereja terdiri dari orang dengan suku jawa, batak, maluku dan papua, maka gereja dapat membuat model pelayanan yang sesuai dengan budaya mereka. Tujuannya adalah agar masing-masing suku dapat mengenali budaya sesamanya dan saling menerima sebagai bagian dalam tubuh Kristus. Kehadiran injil tidak menghapuskan budaya manusia, melainkan menghubungkan antara masingmasing budaya dalam Kerajaan Allah. ${ }^{19}$

Ketiga, mengembangkan model misi yang dinamis. Di dalam injil Lukas dan kitab Kisah Para Rasul telah digambarkan bahwa Tuhan Yesus bergerak mengelillingi berbagai wilayah. Begitu juga dengan para rasul dan jemaat mulamula terus bergerak dari suatu tempat ketempat lainnya. Pola ini relevan dipakai di Indonesia. Dalam konteks budaya yang beragam, seorang misionaris perlu datang ke berbagai wilayah sebagai sasaran misinya. Mereka tidak dapat berteriak dari kejauhan (atas mimbar atau media online) untuk memberitakan injil. Dengan terlibat langsung dalam budaya mereka, maka seorang pemberita injil dapat memberitakan injil sesuai dengan konteks budaya setempat.

Keempat, mengembangkan model pelayanan misi yang kristosentris. Pekerja misi perlu mengembangakan pelayanan yang bermuara pada pemaknaan Kristus melalui budaya masingmasing. Model pelayanan inilah yang memerlukan kerja keras karena pemberita injil harus memahami model budaya dan filosofi yang terkandung dalam budaya tersebut. Dengan memahami filosofi budaya masayarakat lokal, maka pemberita injil dapat memberikan makna kristologis terhadap budaya tersebut sebagai

${ }^{19}$ Richard Bauckham, Bible and Mission: Christians Witness in a Postmodern World (Grand Rapids: Baker Academic, 2009), 110. 
jembatan pemberitaan injil yang kemudian diarahkan kepada pelajaran firman Allah.

\section{KESIMPULAN}

Pemberitaan injil adalah tugas seluruh orang percaya. Sebagaimana gereja terdiri dari berbagai suku bangsa, maka gereja atau orang percaya juga bertanggungjawab dalam pemberitaan injil kepada segala bangsa. Tanpa adanya kesadaran tersebut, maka gereja telah kehilangan hakikat penggilannya karena salah satu mandat gereja adalah bersaksi tentang injil (marturia). Oleh karena itu, gereja pada masa kini perlu mulai memprioritaskan program-program pemberitaan injil untuk menjangkau segala bangsa dengan berbagai macam budaya yang dikandungnya.

Dalam konteks pelayanan misi di Indonesia, para misionaris perlu memahami kondisi masyarakat Indonesia yang memiliki keanekaragaman budaya. Artinya, tidak ada satu metode khusus yang dapat dipakai untuk seluruh masyarakat Indonesia. Pelayanan misi di Indonesia harus bersifat luwes tanpa mengurangi nilai-nilai injil itu sendiri. Jadi, pelayanan misi di Indonesia tidak dapat menerapkan metode yang kaku, sebagaimana diwariskan oleh Zending Belanda, melainkan dilakukan melalui penyesuaian dengan budaya setempat.

Pelayanan misi dalam konteks di Indonesia dilaksanakan dengan mengembangkan prinsip "injil bagi segala bangsa". Yaitu, suatu prinsip yang mengaanggap bahwa injil dapat diterima oleh segala bangsa dengan berbagai macam budayanya. Melalui prinsip tersebut, para misionaris akan berusaha menetapkan metode misi sesuai dengan konteks budayanya dan dapat diterima oleh masyarakat lokal. Dengan demikan akan tercapai puncak pemberitaan injil yaitu, "segala lidah mengaku, Yesus Kristus adalah Tuhan, Bagi kemuliaan Bapa” (Fil. 2:11).

\section{KEPUSTAKAAN}

Bailey, Keneth E. Paul Through Mediteranian Eyes: Cultural Studies In 1 Corinthians. Downers Grove: IVP Academic, 2011.

Bauckham, Richard. Bible and Mission: Christians Witness in a Postmodern World. Grand Rapids: Baker Academic, 2009.

Butler, Phill. "Who's In and Who's Out? Reflections on Our Biblical Understanding of the Gospel." International Buletin of Mission Research 00 (2019): 1-9.

Coppel, Charles A. "Historical Impediments to the of Ethnic Chinese in a Multicultural Indonesia." Antropologi Indonesia 71 (2003): 13-22.

Dewantara, Agustinus Wisnu. "Radikalisme Agama dalam Konteks Indonesia yang Agamis dan Berpancasila." JPAK: Jurnal Pendidikan Agama Katolik 19, no. 1 (April 17, 2019): 1-14. https://ejournal. widyayuwana.ac.id/index.php/jpak/article /view/222.

Friberg, Barbara, Timothy Friberg, and Neva F. Miller. Analytical Lexicon of The New Testament. Grand Rapids: Baker Books, 2000.

Gingrich, Wilbur F. Shorter Lexicon of the Greek New Testament. Edited by Frederick W Danker. 2nd ed. Chicago: The University of Chicago Press, 2007.

Goheen, Michael W. A Light to the Nations: The Missional Church and the Biblical Story. Grand Rapids: Baker Academic, 2011.

Huwae, Esau. "Prinsip Dasar Pemberitaan Injil Menurut Kisah Para Rasul 28:23-31." Kapata 1 (2020): 119-136.

Moo, Douglas J. "The Epistle to The Romans." In The New International Commentary of the New Testament. Grand Rapids: William B. Eerdmans Publishing Company, 2015.

Rheenen, Gailyn Van., and Anthony Parker. Missions: Biblical Fondation and Contemporaries Starategies. Grand Rapids: Zondervan, 2014.

Schnabel, Eckhard J. Rasul Paulus Sang Misionaris: Perjalanan, Strategi dan Metode Misi Rasul Paulus. Yogyakarta: Andi, 2014. 
Suparlan, Parsudi. "Menuju Masyarakat Indonesia yang Multikultural.” Antropologi Indonesia 69 (2002): 98-105.

Talbert, Charles H. Reading Act: Macon: Smyth $\&$ Helwys Publishing, 2005.

Trijono, Lambang. Potret Retak Nusantara: Studi Kasus Konflik Di Indonesia. Yogyakarta: CSPS Books, 2004.

Wasono, Sunu. "Narasi Kebangsaan dalam Karya Budaya Indonesia." In Narasi Kebangsaan Dalam Karya Budaya Indonesia, edited by Wasono Sunu. Jakarta: LIPI Press, 2020.

Yusuf, Muri. Penelitian Kuantitatif, Kualitatif Dan Gabungan. Jakarta: Kencana, 2017.

“Kitab Kisah Para Rasul.” In Alkitab Terjemahan Baru. Jakarta: Lembaga Alkitab Indonesia, 2012. 